\title{
The Rise and Fall of the Basic Income Grant Campaign: Lessons from Namibia
}

\author{
Herbert Jauch, MANWU, Namibia
}

\begin{abstract}
Namibia is still characterised by deep socio-economic inequalities, as economic structures have remained largely intact after independence. Poverty is still widespread and unemployment has remained high with women and youth being particularly affected. In 2002, the Namibian government's Tax Commission proposed a universal cash grant as the most effective way to fight poverty and to reduce inequality. In 2004, the Basic Income Grant (BIG) Coalition was formed consisting of churches, trade unions and non-governmental organisations (NGOs) in support of the proposed grant. It implemented a pilot project to practically demonstrate the effects of the grant. The chosen location was the village of Otjivero where each inhabitant received a monthly cash grant of $\mathrm{N} \$ 100$ (US\$9)beginning in January 2008. A research team closely monitored developments and found that within one year the rates of poverty, child malnutrition and school drop-outs had fallen significantly. Economic activities increased, school results and residents' health status improved while the crime rate and women's economic dependency on men were reduced. Despite these results, the Namibian government did not implement the BIG and the coalition failed to ignite a mass campaign. The country's largest trade union federation did not play an active role and its leadership withdrew from the coalition despite support for the BIG among union members. The introduction of a BIG in Namibia will depend on the ability to the BIG coalition to create pressure 'from below'. Trade unions and youth organisations in particular will have to mobilise their membership and present the demand for the BIG as a form of economic justice. In terms of financial and economic resources, Namibia could easily afford a national BIG and its introduction is a question of political will.
\end{abstract}

\section{Introduction}

When Namibia achieved independence in 1990 it was one of the countries with the highest levels of income inequality. Over one hundred years of apartheid-colonialism had created inequalities in all spheres of life which manifested themselves along racial, class and gender lines. A report by the World Bank (1991) stated that about 5\% of the population (whites) controlled over $70 \%$ of the country's GDP. It is estimated that at Independence some two-thirds of the population were living in conditions of absolute poverty. The entrapment of the black majority in poverty was the product of a systematic system of labour exploitation. Blacks were denied the means to progress to higher levels within the labour market and were largely confined to wage labour at the most basic levels. Excluded from the bulk of managerial, professional and administrative jobs, and with wages below the poverty level, black Namibians found it difficult to move beyond the confines of poverty. However, there was a hierarchy of poverty: the urban poor were better off than people living in peri-urban areas, who in turn were better off than rural families (World Bank, 1991; SWAPO, 1981).

About half of the black working population were engaged in subsistence agriculture in the communal 'homelands'. Approximately 25\% were poorly paid migrant workers, about $14 \%$ were 
employed as poorly paid domestic workers, and the rest were either unemployed or engaged in a variety of informal-sector activities. According to a study by the United Nations Institute for Namibia (UNIN), the income differentials between white and black Namibians far exceeded what could be justified by the skill differentials. Even where they did the same job, there were substantial differences in remuneration (UNIN, 1986).

The white population as a whole benefited from permanent jobs, subsidised housing, health care and superior schools, which were also racially stratified. Almost the entire white labour force had secured employment as professionals, managers, supervisors, technicians, civil servants or as business people in agriculture, industry, commerce and government. A far greater proportion of the national budget was set aside for the white population. Expenditure on health care resources for the white population differed from that reserved for the black population, at a scale of about 10:1. Similar discrepancies existed in the provision of pensions and education services. In 1986-1987, the colonial administration spent some R3 213 per white student compared to R329 per black student (Chase, 1987, cited in Jauch, 1998).

\section{Post-independence Inequalities}

Although apartheid ended with the achievement of independence in 1990 and a liberal, western form of parliamentary democracy was introduced, Namibia remains a deeply divided society today. One of the immediate steps taken by the Namibian government after independence was to reform the provision of basic social services such as education and health care with the aim of ending apartheid discrimination and redressing some of the colonial imbalances. 'Education for all' became a rallying cry of the Ministry as educational services were extended country-wide. The Namibian Constitution guarantees the right to free and compulsory education for ten years (until the age of 16), and government consistently allocated over $20 \%$ of its national budget to the education sector.

A unified system of educational administration was established to replace the ethnic education bodies, and hundreds of schools were built to cater for the increased school enrolment. The Ministry or Education and Culture realised the need to provide sufficient and adequately staffed and equipped classrooms to address the colonial legacy of neglect. Equitable access to schooling was recognised as a critical aspect in the process of redressing inequality (Ministry of Education and Culture, 1993).

Despite having achieved significant improvements in making education accessible, the quality of education is still grossly unequal between different schools and regions. This is reflected in the results of external school examinations at the end of Grades 10 and 12. The best results are usually achieved by private schools, which are expensive and thus only accessible to the elite. The next best results tend to be achieved by the former white schools in towns while the worst results are found in rural schools.

In the economic sphere the post-independence changes were very cautious and far from transformative. Despite rhetorical commitment to socialism in the 1970s and early 1980s, Namibia's ruling party and former liberation movement, the South West Africa People's Organisation (SWAPO), signalled its willingness to follow 'pragmatic' policies even before it took power. SWAPO regarded national independence (and not the 'proletarian revolution') as the primary goal of its struggle. This was clearly reflected in the party's policy proposals for an independent Namibia in the late 1980s as well as the election manifesto of 1989. When SWAPO's 'Economic Policy Position Document' was released in November 1988, it no longer called for the nationalisation of key industries but instead promised 'fair and just compensation in those instances where state acquisition of assets from private hands is considered necessary for the rebuilding and restructuring of

Global Labour Journal, 2015, 6(3), Page 337 
Namibia's national economy' (The Namibian, 27 January 1989).

\section{Unemployment and Poverty}

The gradual change that occurred in Namibia during the past twenty-five years meant that the country retained a high Gini co-efficient of around 0.6, and unemployment remained a serious challenge. In 1997 Namibia conducted its first Labour Force Survey which recorded an overall unemployment rate of $34.5 \%$ (according to the broad definition, which is being without work while being available to work) (Ministry of Labour, 2000). This figure increased to 36.7\% in 2004 and further to a record 51.2\% in 2008. The situation for women and young Namibians was far worse, with youth unemployment reaching around $75 \%$ in 2008 as indicated in Table 1.

Table 1: Percentage Unemployment, 1997-2013

\begin{tabular}{|l|r|r|r|r|r|r|}
\hline Year & $\mathbf{1 9 9 7}$ & $\mathbf{2 0 0 0}$ & $\mathbf{2 0 0 4}$ & $\mathbf{2 0 0 8}$ & $\mathbf{2 0 1 2}$ & $\mathbf{2 0 1 3}$ \\
\hline Overall unemployment & 35 & 34 & 37 & 51 & 27 & 30 \\
\hline Unemployment among women & 40 & 39 & 43 & 58 & 32 & 33 \\
\hline $\begin{array}{l}\text { Unemployment among youth } \\
\text { (15-24 years) }\end{array}$ & 58 & 67 & 61 & 75 & 52 & 61 \\
\hline
\end{tabular}

Source: Namibia Labour Force Surveys 1997, 2000, 2004, 2008, 2012 and 2013

However, the Labour Force Survey of 2012 presented new figures which contradicted the trend. It found an overall unemployment rate of 'only' $27.4 \%$ with a rate of $31.8 \%$ among women and $52 \%$ among youth. Furthermore, the total number of employed people in Namibia, which had declined from 401203 in 1997 to 385329 in 2004 and further to 331444 in 2008 suddenly increased to 630094 in 2012. This reversal of unemployment trends is not based on new jobs being created but resulted from a new methodology to measure employment: the 2012 Labour Force Survey probed if a person was engaged in any type of economic activity of one hour in the last week, including looking after animals, fixing a fence, catching fish, collecting firewood, repairing household items, etc. Anybody engaged in any such activity for at least one hour was then counted as employed, bringing down the official unemployment rate. Consequently almost all Namibians engaged in rural subsistence agriculture as well as those looking after families at home were classified as employed in 2012. However, despite these statistical changes there is no doubt that unemployment is still a huge challenge for many Namibians today. The figures for 2013 confirm that unemployment is still rising, particularly among young people.

Namibia's widespread unemployment is made worse by the fact that many Namibian households (close to 50\%) depend on one main wage earner and thus unemployment has an immediate effect on household survival.

According to the World Bank, Namibia has made significant strides in economic and social progress, especially when it comes to social spending. It notes that the country is in the top ten globally in terms of percentage of GDP spent on education, and ranks second only to South Africa on the continent when it comes to expenditure on health (World Bank, 2008). Namibia experienced steady if unspectacular economic growth, hovering around the 3-4\% range, while inflation remained in the range of $2-11 \%$, mostly around $7 \%$ during the past decade (Jauch, Edwards and Cupido, 2009).

However, poverty still affects a large number of Namibians. It can be measured in different ways and the methodology used will determine to a significant extent who will be counted as poor.

Global Labour Journal, 2015, 6(3), Page 338 
In 2004, the Namibian government used the food-ratio method, whereby the definition of poverty is determined solely by the proportional expenditure on food: those who spend at least $60 \%$ of their total expenditure on food are regarded as poor while those who spend at least $80 \%$ are regarded as 'severely poor'. Poverty can, however, be measured and assessed very differently, for example, by establishing a 'basket' of essential food and non-food items needed for household survival. A monetary value for such a basket could be calculated and then used as the standard for measuring poverty. This was attempted by the University of Port Elizabeth through the 'Household Subsistence Level' (HSL) (Potgieter, 1997). Adjusting these figures by the annual inflation rate would have meant that about $82 \%$ of Namibians were living below the poverty line of $\mathrm{N} \$ 399.80$ per person per month. Applying the crude international poverty line of US $\$ 1$ per person per day would have resulted in $62 \%$ of Namibians being regarded as poor (LaRRI, 2006; also see Table 2).

In 2008, the Central Bureau of Statistics (CBS) adopted a new approach to measuring poverty by determining a food basket based on actual consumption patterns in low-income households plus the cost of certain non-food requirements. At 2004 price levels, adult persons with consumption levels of below $\mathrm{N} \$ 262$ were regarded as poor and those with consumption levels of below $\mathrm{N} \$ 184$ as extremely poor. This resulted in $27.6 \%$ of Namibians being classified as poor, with $13.8 \%$ being extremely poor (CBS, 2008).

Table 2: Poverty in Namibia according to various measures

\begin{tabular}{|l|l|c|}
\hline Source & Measure & $\begin{array}{l}\text { \% of Namibians } \\
\text { living in poverty }\end{array}$ \\
\hline $\begin{array}{l}\text { Household Subsistence Level } \\
\text { (University of Port Elizabeth) }\end{array}$ & $\begin{array}{l}\text { Basket of essential goods and } \\
\text { services }(\mathrm{N} \$ 399.80 \text { per person } \\
\text { per month in 2004) }\end{array}$ & 82 \\
\hline Crude international poverty line & US\$1 per day & 62 \\
\hline $\begin{array}{l}\text { Namibia Household Income } \\
\text { and Expenditure Survey (2004) }\end{array}$ & $\begin{array}{l}\text { At least } 60 \% \text { of income spent } \\
\text { on food }\end{array}$ & 28 \\
\hline $\begin{array}{l}\text { Review of Poverty and } \\
\text { Inequality in Namibia (CSI, } \\
2008)\end{array}$ & $\begin{array}{l}\text { Basic needs (N\$262.45 per } \\
\text { person per month in 2004) }\end{array}$ & \\
\hline
\end{tabular}

Sources: LaRRI, 2006; Central Bureau of Statistics, 2008

No matter which definition is applied, there is no doubt that unemployment, inequality and poverty are key challenges for Namibia today. Although there is a universal old age pension of $\mathrm{N} \$ 600$ for every person reaching 60 years of age, there is no universal social protection as those outside formal employment are practically excluded from the provisions of the Social Security Act. There is also no insurance against unemployment and no national health insurance. However, according to World Bank figures, Namibia is an upper-middle income country with a GDP of US $\$ 12.3$ billion and a per capita income of US $\$ 4700$ (www.worldbank.org/en/country/namibia). This figure was simply derived by dividing the country's GDP by the number of inhabitants. The resulting average of US $\$ 4700$ hides the fact that most GDP benefits only a small elite and the transnational corporations controlling the country's natural resources while the vast majority of Namibians have to survive on just a fraction of the average GDP per capita.

\section{The Proposal for a Basic Income Grant}

The first suggestion for a Basic Income Grant (BIG) came from the Namibian government's 
tax commission (NAMTAX), which proposed a universal grant as the most effective way to fight poverty and to reduce inequality in a short period of time. The Commission suggested that the grant should be financed through a progressive expenditure tax on the affluent (Haarmann et al., 2009), and pointed out that sustainable economic development in Namibia would be unachievable if poverty and inequality were not redressed. At the time (2002), NAMTAX proposed that the universal grant should be set at not less than $\mathrm{N} \$ 70$ per person per month, and calculated the total cost to be $\mathrm{N} \$ 1.156$ billion per year. It proposed that this could be financed through an increase in the value-added tax of $6.5 \%$ or alternatively by introducing a bed tax or tourist levy and by increasing the excise tax on alcohol, tobacco, luxury cars and so on. In such a case, a VAT increase of $4.5 \%$ would suffice (Haarmann, 2005). Although the Commission's recommendations were not widely circulated and initially hardly debated in public, they provided an impetus for the later formation of Namibia's BIG Coalition and the campaign for the introduction of a BIG in Namibia.

In 2004, spearheaded by the Evangelical Lutheran Church in the Republic of Namibia (ELCRN), a cross-section of Namibian civil society organisations set up a Coalition to promote the introduction of a BIG for all Namibians. The BIG Coalition brought together different umbrella bodies such as the Council of Churches in Namibia (CCN), the National Union of Namibian Workers (NUNW), the Namibian NGO Forum (NANGOF) and the Namibian Network of AIDS Service Organisations (NANASO) as well as the Legal Assistance Centre (LAC) and the Labour Resource and Research Institute (LaRRI). Later on, the National Youth Council (NYC) and the Church Alliance for orphans (CAFO) also joined the Coalition. The ELCRN's Desk for Social Development (DfSD) provided secretarial services for the Coalition and co-ordinated its work. The idea of a BIG found support even beyond the Coalition's member organisations as numerous groups and individuals, including local businesspeople, churches and international agencies, gave support and encouragement. Some government ministers and senior officials also showed interest and indicated their willingness to develop a more universalistic system of social protection and economic empowerment (Haarmann et.al., 2009).

The proposal regarding the BIG Coalition was in line with the NAMTAX recommendation and stated that all Namibians should have a citizenship right to a Basic Income Grant of not less than $\mathrm{N} \$ 100$ per month until they became eligible for the social pension upon turning 60 years of age. The BIG thus constituted a cash transfer which would allow recipients to decide freely how to spend the money, taking their personal circumstances into account. Thus the BIG was envisaged as an act of empowerment by giving people enhanced freedom and personal responsibility. It was conceptualised as an economic right and not as an act of charity. The chairperson of the BIG Coalition, Bishop Dr Zephania Kameeta (2009: viii), stated, 'I am convinced that the BIG is not only able to eradicate destitution, hunger and malnutrition, but that it lays a strong foundation for economic empowerment, responsibility and ownership taking. The BIG, by restoring the human dignity of people, frees people to become active and proud members of this society'.

The proposed BIG was essentially seen as an effective instrument to fight poverty, introduce an economic right and provide dignity. The proposed amount of $\mathrm{N} \$ 100$ (about $€ 10$ or US\$12 at the time) constituted only about a third of what was needed to rise above the poverty level. Thus the BIG at that low level was insufficient on its own to wipe out poverty. However, it would have been enough to guarantee some basic food security and thus was a step towards the realisation of the basic right of each person to enjoy a reasonable standard of living. As set out in the International Covenant on Economic, Social and Cultural Rights (ICESCR), ${ }^{1}$ a minimum income should be regarded as a basic human right independent of the right to work. Article 11 recognises the right of every person to enjoy an adequate standard of living, including food, clothing and housing, without any precondition to be fulfilled. The right to work is regarded as another human right but work is not a precondition for the enjoyment of a minimum income that covers basic needs (Künnemann,

Global Labour Journal, 2015, 6(3), Page 340 
2007).

Article 95 of the Namibian Constitution obliges the state to promote and maintain the welfare of the people by inter alia: promoting policies aimed at creating 'equality of opportunity for women that enables them to participate fully in all spheres of society'; by enacting laws that promote the health and strength of workers; by actively encouraging the formation of independent trade unions; by ensuring fair and reasonable access to public facilities for all citizens; by ensuring the pensioners receive a regular and adequate pension; by enacting legislation that ensures that the unemployed, incapacitated and disadvantaged enjoy social benefits and amenities; by ensuring that workers are paid a living wage for the maintenance of a decent standard of living; by consistently 'planning to raise and maintain an acceptable level of nutrition and standard of living of the Namibian people and to improve public health'; by encouraging the mass of the population to influence government policy by debating its decisions; etc. Thus the proposals for a BIG squarely fit into this constitutional provision and Namibia's BIG Coalition was hopeful that it could convince and encourage government to implement the grant.

The main focus of the Coalition's strategy in the first three years was to engage policy makers and to convince them that a BIG was both an efficient and an affordable tool to fight poverty. It argued that the BIG was a basic economic right in line with the welfare provision of the Namibian Constitution. Given the low levels of Namibia's indebtedness, the low administrative costs of a BIG pay-out and the broad level of its representativeness, the Coalition believed that it could push government towards the implementation of a national BIG. However, things turned out differently.

\section{The Need to Campaign}

Despite the seemingly convincing arguments for the viability of a BIG, the Namibian government remained divided. The Finance Ministry in particular remained doubtful as the International Monetary Fund (IMF) and World Bank strongly advised against a universal cash grant although it would have required only around 5\% of Namibia's national budget, which could have been raised through tax adjustments. The BIG Coalition thus realised that it needed to increase the pressure and introduce a visible campaign to force government's hand. The Coalition's chairperson, Bishop Kameeta, suggested that the best way to convince government was to show how a BIG would work in practice, and thus the Coalition decided to select a particular town, village or settlement where a BIG could be implemented and to document its impact. The Coalition then travelled to various regions to look for possible locations and chose the settlement of Otjivero in the Omitara district, about $100 \mathrm{~km}$ east of Windhoek. This settlement became the site of the BIG pilot project in 2008 and 2009. It was funded through local and international donations, mostly from churches in Germany.

\section{The BIG in Otjivero}

In 2007, Otjivero was a small settlement of about a thousand people who lived on a strip of state-owned land leading to the Otjivero dam. The surrounding land consisted of commercial farms, mostly owned by German-speaking farmers. Many of the Otjivero residents were former farm workers who had lost their jobs and had then been evicted from the farms with nowhere else to go. Most lived in shacks made of plastic, wood and zinc, and poverty was widespread. The BIG Coalition visited the settlement several times to discuss the possibility of introducing a BIG pilot there.

The Otjivero community met under the central 'village tree' and asked critical questions about the BIG as they were suspicious about the promises of development aid that had been made in past

Global Labour Journal, 2015, 6(3), Page 341 
years. Also, the idea of a BIG was completely new to the residents, and the Coalition could only guarantee the grant for a two-year period during which the Namibian government needed to be convinced to introduce the BIG nationally. The community agreed to become the site of the BIG pilot phase and embarked on their own process of mobilisation and conscientisation without any outside interference. The residents decided to elect an eighteen-member 'BIG Committee' to guide the pilot project within the community and to assist residents as well as the BIG Coalition whenever the need arose. The committee consisted of local teachers, the nurse, representatives of the police as well as small business people such as shebeen ${ }^{2}$ owners and other community members (Haarmann et al., 2009).

The community felt that, unlike other 'development projects', the BIG pilot project gave them ownership of the process and responsibility for the outcome. They wanted to ensure the best possible impact of the BIG on the lives of individual residents and the wider community. Recipients of the grant could freely choose what to do with the money although the community's BIG Committee developed a strict code of conduct and wanted to ensure that residents made the best possible use of their BIG payments. Thus the committee understood its role as raising awareness and providing advice. The committee was conscious of the widespread problem of alcohol abuse and paid special attention to this problem during the pilot project. Shebeen owners were represented on the committee and agreed not to open their shebeens on the days the BIG was paid out. The challenge of alcoholism was openly discussed from the outset and addressed through a process of community discussions (Haarmann et al., 2009).

The role of the BIG Coalition was merely to facilitate the registration of all residents for the BIG payments, to issue smart cards for easy identification and payments, and to document the socio-economic changes resulting from the BIG. Initially a private company was responsible for the monthly pay-out but this was changed to the state-owned Namibia Post Office (Nampost) which set up a satellite post office in Otjivero to facilitate easy access for the residents. The residents opened post office accounts and Nampost agreed to two free withdrawals per person per month. Overall the administrative costs for facilitating the BIG payments amounted to less than $10 \%$ of the amount paid out, which made the BIG one of the most cost-effective social payments.

Developments in Otjivero were closely monitored by a team of local and international social scientists. They first documented the socio-economic conditions in Otjivero ahead of the introduction of the BIG and then continuously monitored the changes that occurred after its implementation. Four complementary methods were used: after the initial baseline study, panel surveys were conducted in July and November 2008; information was gathered from key informants (such as the local nurse, teachers, the police, etc.); and detailed case studies of individuals living in Otjivero-Omitara were carried out (Haarmann et al., 2009).

\section{The Results}

The research report outlined the key changes that occurred in Otjivero within twelve months of the introduction of the BIG:

- Before the introduction of the BIG, Otjivero was characterised by unemployment, hunger and poverty. Most residents had settled there because they had nowhere else to go, their lives were shaped by deprivation and they had little hope for the future.

- The introduction of the BIG ignited hope and the community responded by establishing its own eighteen-member committee to mobilise the community and to advise residents on how to spend the BIG money wisely. This suggests that the introduction of a BIG can effectively assist with community mobilisation.

Global Labour Journal, 2015, 6(3), Page 342 
- As the BIG was only introduced in one particular location, there was a significant migration towards Otjivero. Impoverished family members moved into Otjivero, attracted by the BIG. Even if migrants themselves did not receive the grant, this points to the need to introduce the BIG as a universal national grant in order to avoid migration to particular regions, towns or households.

- Since the introduction of the BIG, household poverty has dropped significantly. Using the food poverty line, $76 \%$ of residents fell below this line in November 2007 . This was reduced to $37 \%$ within one year of the BIG. Among households that were not affected by inmigration, the rate dropped to $16 \%$. This shows that a national BIG would have a dramatic impact on poverty levels in Namibia.

- The introduction of the BIG has led to an increase in economic activity. The rate of those engaged in income-generating activities (above the age of 15) increased from 44\% to 55\%. Thus the BIG enabled recipients to increase their work both for pay, profit or family gain as well as self-employment. The grant enabled recipients to increase their productive income earned, particularly through starting their own small business, including brick-making, baking of bread and dress-making. The BIG contributed to the creation of a local market by increasing households' buying power. This finding contradicts critics' claims that the BIG would lead to laziness and dependency.

- The BIG resulted in a huge reduction of child malnutrition. Using a WHO measurement technique, the data shows that children's weight-for-age has improved significantly in just six months from $42 \%$ of underweight children in November 2007 to $17 \%$ in June 2008 and $10 \%$ in November 2008.

- HIV-positive residents' access to anti-retrovirals (ARVs) was hampered by poverty and a lack of transport before the BIG was introduced. The BIG enabled them to afford nutritious food and gain access to the medication. This was further enhanced by government's decision to make ARVs available in Otjivero, freeing residents from the need to travel to Gobabis, a town situated over a hundred $\mathrm{km}$ away.

- Before the introduction of the BIG, almost half of the school-going children did not attend school regularly. Pass rates stood at about $40 \%$ and drop-out rates were high. Many parents were unable to pay the school fee. After the introduction of the BIG, more than double the number of parents paid school fees $(90 \%)$ and most of the children now have school uniforms. Non-attendance due to financial reasons dropped by $42 \%$ and this rate would have been even higher without the effects of migration towards Otjivero. Drop-out rates at the school fell from almost 40\% in November 2007 to 5\% in June 2008 and further to almost $0 \%$ in November 2008.

- The residents have been using the settlement's health clinic much more regularly since the introduction of the BIG. Residents now pay the $\mathrm{N} \$ 4$ payment for each visit and the income of the clinic has increased fivefold from $\mathrm{N} \$ 250$ per month to about $\mathrm{N} \$ 1300$.

- The BIG has contributed to a significant reduction of crime. Overall crime rates - as reported to the local police station - fell by $42 \%$ while stock theft fell by $43 \%$ and other theft by nearly $20 \%$.

- The introduction of the Basic Income Grant has reduced the dependency of women on men for their survival. The BIG has given women a measure of control over their own sexuality, freeing them to some extent from the pressure to engage in transactional sex.

Global Labour Journal, 2015, 6(3), Page 343 
- The criticism that the BIG is leading to increasing alcoholism is not supported by empirical evidence. The community committee is trying to curb alcoholism and has reached an agreement with local shebeen owners not to sell alcohol on the day of the pay-out of the grants. (Haarmann et al., 2009).

Encouraged by these results, the BIG Coalition was optimistic that it could convince the Namibian government to introduce a Basic Income Grant. It distributed the findings widely in the local media, held regular media briefings, participated in radio and TV programmes, invited journalist to visit Otjivero and also made the results known internationally resulting in several print and electronic media journalists visiting the settlement. The Coalition also embarked on a series of meetings across the country to introduce the idea of a BIG and to share the impact it has had in Otjivero. Some of these meetings were addressed by residents of Otjivero themselves to facilitate a direct exchange between them and Namibians in other regions of the country. The Coalition had hoped that these exchanges would lead to a growing demand for the introduction of a BIG elsewhere. In addition, the leadership of the Coalition's member organisations held meetings with some of the country's key political leaders, administrators and regional politicians, hoping to convince them about the benefits of a national BIG.

In order to create a large number of cadres to campaign for a national BIG, the Coalition convened a workshop for young people from all corners of Namibia who supported the idea of a BIG and were thus trained to become 'BIG ambassadors' in their respective regions. They were introduced to the ongoing challenges of poverty and inequality and how the BIG could play a role in redressing them. Finally, the Coalition invited Namibian parliamentarians to visit Otjivero to gain first-hand impressions about the impact of the BIG there. Most were from the ruling SWAPO party and although some had reservations before the visit, they were all convinced of the effectiveness of the BIG after gaining personal insights in Otjivero.

\section{Resistance to the BIG}

It thus seemed that the introduction of a national BIG was possible. The results of the BIG in Otjivero were generally appreciated in the public debates and several politicians supported the idea, but there were also dissenting voices. A German economist who worked for the now-defunct Namibia Economic Policy Research Unit (NEPRU) at the time, tried to portray the research results from Otjivero as unscientific and biased and cast doubt about the real impact of the BIG (see for example R. Osterkamp in New Era, 24 October 2008, and in Allgemeine Zeitung, 27 October 2008). Resistance against the BIG also came from the IMF which used inflated figures regarding the costs of a national BIG and warned that it would be unaffordable. The IMF did not distinguish between the nominal costs of a BIG and the real ones, ignoring the fact that pensioners would not receive the BIG. The IMF also ignored the proposal that the BIG would be nominally paid to higherincome earners but could be recovered by the fiscus immediately through an adjustment in the personal tax rates. Even after a meeting with the BIG Coalition during which the IMF had to admit that its cost calculations were wrong, it continued circulating the wrong figures in its press statements.

Some local politicians then joined the bandwagon and questioned if a BIG would be a suitable strategy to wipe out poverty. They also questioned why the grant should be given to everybody and not just to the poor, and argued that it might be better to create jobs instead of giving 'hand-outs'. Such arguments ignored the emancipatory aspect of a BIG as well as the country's growing levels of unemployment which made the suggested choice between a job and the BIG a mockery.

Although the Namibian government had not pronounced itself officially on the BIG and 
seemed divided, Namibian President Hifikepunye Pohamba took a position against the grant in early 2010 after delivering a speech in Parliament. When asked by an Opposition Member of Parliament (MP) about his views on the proposed BIG, he replied that he was afraid it might make people lazy. This signalled that the Namibian government had no intention to introduce a BIG, and the BIG campaign suffered a heavy set-back. President Pohamba then repeated his objection to the BIG in Parliament in 2014 (The Namibian, 4 April 2014). Although some politicians still privately supported the idea of a BIG, the MPs of the ruling party started echoing the President's sentiments which ignored the available evidence form Otjivero. The BIG had not made people lazy but on the contrary enabled economic activities at a very basic level such as baking bread, sewing clothes, fixing shoes, operating hair salons and making bricks. These activities were sustained by the BIG, which created a local market as a precondition for sustained, mostly informal economic activities.

\section{The Role of Trade Unions}

The country's largest trade union federation, the National Union of Namibian Workers (NUNW) joined the BIG Coalition when it was formed in 2004. With a total membership of about 60000 to 70000 spread among eight industrial unions organising in all sectors of the formal economy, the NUNW was a critical constituent organisation and had proven its ability to organise large numbers of workers in the run-up to Namibia's independence. Even after independence, the NUNW had political clout and it supported the BIG idea as part of a strategy to fight poverty and to secure a basic standard of living for all. The NUNW's acting general secretary Peter Naholo stated:

as a labour movement ... we will always remain firm and ready to embrace and support the struggle for social justice and economic emancipation. It has always been and remains our sacred belief that there will be nothing about us without us as workers. Therefore we have come out in our multitudes today to support this noble initiative [Basic Income Grant]. In view of the current onslaught on the job opportunities of our members whereby retrenchments and job losses are the order of the day, obviously the Basic Income Grant would ultimately serve as a fall-back position for the retrenched workers. When a worker is retrenched, it simply means loss of income. Loss of income means loss of hope. Without hope, life is shattered. Therefore, we need to provide hope for them, we must enable them to appreciate that there is always life after retrenchment (quoted in Haarmann, 2005: 8).

This indicates that although the NUNW understood the BIG as part of the struggle for socioeconomic justice, it conceptualised the BIG more as a social safety net than as an economic entitlement. This conceptualisation might explain why Namibian unions never regarded the BIG as a strategic priority in the struggle for economic emancipation.

For several years, the NUNW expressed support for the BIG campaign and attended some of the Coalition meetings. It was due to political developments within the federation that labour's contribution to the BIG campaign declined in subsequent years. During the NUNW's Congress of 2006, the federation became deeply divided over the question of political succession within the ruling SWAPO party to whom the NUNW is affiliated. The NUNW basically split into two camps, one supporting the founding President Sam Nujoma and his chosen successor Hifikepunje Pohamba, and the other faction supporting Hidipo Hamutenya. The acting NUNW general secretary at the time, Peter Naholo, was part of the group supporting Hamutenya. Naholo was suspended just ahead of the NUNW Congress and subsequently outvoted. The Congress left the NUNW deeply divided and the new leadership consisted essentially of people supportive of the

Global Labour Journal, 2015, 6(3), Page 345 
Nujoma group (Jauch, 2007). They treated the BIG Coalition with some suspicion, questioned the Coalition's political motives and consequently played hardly any role in the BIG campaign.

In July 2010, following Presidents Pohamba's dismissal of the BIG idea, the NUNW's Central Executive Committee (CEC) decided to resign from the BIG Coalition. This decision was taken without a mandate from members, as became apparent during the NUNW Congress of September 2010. The Congress was held under the theme 'Back to Basics: Workers Take Control of Trade Unions for Economic Emancipation'. It promised heated debates, and two issues in particular were expected to be contested, namely the NUNW's withdrawal from the BIG Coalition and the corruption and mismanagement surrounding the Government Institutions Pension Fund (GIPF). Although some union leaders tried to stifle debate on the BIG, workers resisted from the floor and discussed the issue for several hours. In the end, they decided that the NUNW should rejoin the BIG Coalition and that the BIG should be part of a broader initiative to fight poverty and to effect structural economic transformation.

This decision was significant in various respects: firstly it contradicted the expressed sentiments on a national BIG as expressed by Namibia's former Prime Minister Nahas Angula and President Pohamba, and it nullified the decision taken by the NUNW's CEC just weeks before the Congress. This was a clear sign how removed some trade union leaders had become from their base and pointed to a lack of accountability through mandates and feed-backs within the labour movement. The Congress decision on the BIG was meant not only to re-direct the NUNW leadership but also to increase the pressure on the Namibian government to seriously consider the introduction of a national BIG as a tool to fight poverty. Workers expressed their views loud and clear, and the resolutions passed were supposed to guide the NUNW leadership in the years to come (Jauch, Windhoek Observer, 10-16 September 2010). However, the deep divisions within the NUNW and political pressure to 'soften' the resolutions taken meant that the workers' mandate was never implemented. The NUNW did not rejoin the BIG Coalition and the elected NUNW general secretary was (unfairly) dismissed while the elected NUNW president was suspended in 2012 . These internal union struggles weakened the struggle for a BIG substantially as the NUNW failed to use its political influence to shift the public debate and the government position in line with the views expressed by workers during the 2010 Congress.

Namibia's second trade union federation, the Trade Union Congress of Namibia (TUCNA), never participated in the public BIG debates. The federation felt snubbed by the BIG Coalition as only the NUNW had been invited when the coalition was formed. However, TUCNA is sympathetic to the idea and mentions the BIG in its national development policy as a measure to redress poverty (M. Kavihuha, general secretary, personal communication, 7 November 2014). Like the NUNW, TUCNA regards the BIG as a social protection tool rather than a step towards economic emancipation.

\section{A Dead-end?}

Despite the promising results in Otjivero and the growing interest in the idea of a universal BIG, the Coalition did not manage to ignite a sustainable campaign to put government under pressure to implement the grant. When it became apparent that the Namibian government would not be easily swayed, significant parts of the Coalition's member organisation withdrew their active participation. The churches, which had been the driving force behind the BIG Coalition, were reluctant to take a more challenging position and did not want to differ openly with government over the BIG. The youth organisations under the NYC hardly attended coalition meetings and did not propose or ignite any grassroots mobilisation around the BIG, while the NGOs remained equally passive. Even the youth volunteers that had been recruited as BIG ambassadors did not 
manage to mobilise visible support for a national BIG in their respective regions, and thus there was very little pressure on the Namibian government to change its stance.

Unlike in the late 1980s when the student and labour movements played a central role in mobilising their members and supporters in large numbers, the BIG campaign remained at the level of providing good arguments for its implementation and pointing to the benefits to be derived in terms of a substantial poverty reduction. Trade unions should have raised the issue of economic justice as a central theme and thrown their weight behind the BIG campaign since the grant would have constituted a practical step towards the implementation of an economic right. It would have taken household incomes beyond the confines of wage labour, but Namibian unions did not seize this opportunity. This was possibly the most crucial shortcoming in Namibia's efforts to introduce the BIG.

The inhabitants of Otjivero are now facing a dramatic worsening of their living conditions, and some of the achievements made since the introduction of the BIG are under threat. BIG payments are no longer regular and depend on available donations. This makes the economic basis for survival unpredictable for the inhabitants of Otjivero and also undermines the emancipatory aspect of the grant. Inhabitants once again have to rely on others for survival in contradiction to the BIG's aim of ensuring a basic economic right. Critics and opponents of the BIG thus have cynically used this opportunity to claim that Otjivero has shown that the BIG in unsustainable.

Following the presidential and parliamentary elections of 2014, a new administration took office in March 2015. The new President, Dr Hage Geingob, announced that the eradication of poverty would be a key focus of his administration, and he established a new Ministry of Poverty Eradication and Social Welfare, headed by the former chairperson of the BIG Coalition, Bishop Kameeta. This has given renewed hope that the Namibian government might consider the introduction of a national BIG as one of its key interventions to fight poverty.

\section{Conclusion}

The formation of a broad and representative coalition of various civil society organisations including unions, churches and NGOs was certainly an important step toward generating support for a Basic Income Grant. Unlike other social grants, the BIG would have constituted an economic right and thus is a qualitatively different intervention. The pilot project in Otjivero has clearly shown that a host of social and economic benefits will be derived from the BIG, and that the 10\% administrative costs are far smaller than those of any other existing programme, making the BIG a highly cost-effective grant. The positive results from the pilot project were not only recognised inside Namibia but also internationally, for example when the UN Special Representative Magdalena Sepúlveda visited Otjivero in 2012 and pointed out that the BIG had achieved many positive results (http://www.az.com.na/soziales/initiative-gegen-armut-gelobt.156809.php). She supported the implementation of a country-wide BIG as an effective tool to fight poverty.

Means-tested grants do not constitute economic rights and require substantial resources for their administration. Means-testing also leads to stigmatisation and exclusion of some people who are meant to be reached. In addition, means testing can lead to corruption and clientelism and is likely to have unintended side-effects. It can divide communities like Otjivero and can lead to unintended punishment of those who do find a job. For example, if only people earning less than R800 per month were entitled to receive a BIG, an unemployed person who would find a job as a farm worker, earning R900 would then be punished by losing the grant.

In Namibia, like elsewhere in Africa, most household incomes are irregular and can change from month to month. Thus means-testing would have to be conducted on a continuous basis, and households would be encouraged to understate their real income in order to receive the grant. A

Global Labour Journal, 2015, 6(3), Page 347 
universal BIG, on the other hand, would be easy to calculate in terms of costs, it would guarantee all households a certain amount of income security, it would reduce the dependency of many women on their male partners, and it would guarantee everybody an income outside the exploitative relations of wage labour. Vulnerable workers in low-income jobs would also be afforded the opportunity to reject some of the most exploitative jobs as their survival would not solely depend on those jobs.

Despite these convincing arguments and the lived experiences in Otjivero, the introduction of a BIG in Namibia will essentially depend on the ability to the BIG coalition to re-ignite the campaign and to create pressure 'from below'. This will require particularly trade unions and youth organisations to mobilise their membership. Namibia's labour movement could have utilised the opportunity to become a central driver of the BIG campaign by shifting the debate beyond merely addressing poverty towards a conceptualisation of the BIG as a step towards the realisation of guaranteed economic rights; it has not done so. Given Namibia's pervasive levels of socio-economic inequality, trade unions could also have linked the demand for a BIG to further redistributive measures in favour of their working-class constituency and the poor in general. They should have located the BIG at the centre of a debate on the need for socio-economic justice in Namibia today. TUCNA's recent development policy document of 2015 calls for the creation of a 'sovereign wealth fund' into which a substantial share of the proceeds from natural resources such as land, minerals, diamonds and fish could be paid. TUCNA argues that such a fund must benefit the vast majority of the population instead of leaving the benefits from the country's resources in the hands of a small elite.

In terms of financial and economic resources, there is no doubt that Namibia could easily afford a national BIG, even at a higher level than the one used for the pilot. It is merely a question of political will, as the resistance does not only come from within government but also from international organisations like the IMF and World Bank, and to some extent even the ILO who use their influence to lobby for social protection but advise against more substantive redistributive measures that entrench economic rights. Progressive organisations, in particular trade unions, thus need to build a counter-hegemony if they want to make the BIG a reality. It is certainly a building block for a more inclusive and socially just society and it presents an opportunity for unions to show that they are concerned with more than just their members' bread-and-butter issues.

\section{NOTES}

1 The ICESCR is a multilateral treaty adopted by the United Nations General Assembly on 16 December 1966. It came into force from 3 January 1976 and commits its parties to work toward the granting of economic, social and cultural rights (ESCR) to individuals, including labour rights and the right to health, the right to education and the right to an adequate standard of living. As of 2013, the Covenant had 160 parties.

${ }^{2}$ A shebeen is a type of 'informal bar' situated within residential areas. Shebeens are very common in townships in Southern Africa, and some operate with licences while others are unlicensed.

\section{REFERENCES}

Central Bureau of Statistics, National Planning Commission (2008) A Review of Poverty and Inequality in Namibia. Windhoek: Central Bureau of Statistics, National Planning Commission.

Chase, N. (1987) Some Notes on Peoples Education in Namibia. In Namibia in Perspective, edited by 
G. Toetemeyer., V. Kandetu and W. Werner. Windhoek: CCN.

Haarmann, C. and Haarmann, D. (2005) The Basic Income Grant in Namibia. Resource Book. Windhoek: ELCRN.

Haarmann, C., Haarmann, D., Jauch, H., Shindondola-Mote, H., Natrass, N., Van Niekerk, I. and Samson, M. (2009) Making the Difference! The BIG in Namibia. Windhoek: BIG Coalition.

Jauch, H. (1998) Affirmative Action in Namibia: Redressing the Imbalances of the Past? Windhoek: New Namibia Books.

Jauch, H. (2007) Between Politics and the Shopfloor: Which Way for Namibia's Labour Movement? In Transitions in Namibia. Which Changes for Whom? edited by H. Melber. Uppsala: Nordic Africa Institute.

Jauch, H., Edwards, L. and Cupido, B. (2009) A Rich Country with Poor People. Inequality in Namibia. Windhoek: Labour Resource and Research Institute.

Kameeta, Z. (2009) Foreword. In Making the Difference! The BIG in Namibia, edited by C. Haarmann and D. Haarmann. Windhoek: ELCRN.

Künnemann, R. (2007) Grundnahrungseinkommen: EinuniversellesMenschenrecht? Netzwerk Grundeinkommen, Newsletter Nr. 11, September 2007.

Labour Resource and Research Institute (2006) The Wage Bargaining Report 2005. Windhoek: LaRRI.

Ministry of Education and Culture (1993) Toward Education for All. Windhoek: Gamsberg Macmillan.

Ministry of Labour (2000) The Namibia Labour Force Survey 1997: Final Report. Windhoek: Ministry of Labour and National Planning Commission.

Ministry of Labour (2002) The Namibia Labour Force Survey 2000: Final Report. Windhoek: Ministry of Labour and National Planning Commission.

Ministry of Labour and Social Welfare (2006) Namibia Labour Force Survey 2004: Report of Analysis. Windhoek: Ministry of Labour and Social Welfare.

Ministry of Labour and Social Welfare (2010) Namibia Labour Force Survey 2008: Report of Analysis. Windhoek: Ministry of Labour and Social Welfare.

Namibia Statistics Agency (2013) The Namibia Labour Force Survey 2012. Report. Windhoek: NSA.

Namibia Statistics Agency (2014) The Namibia Labour Force Survey 2013. Report. Windhoek: NSA.

Potgieter, J. F. (1997) The Household Subsistence Level. Port Elizabeth: UPE.

Republic of Namibia (1990) The Constitution of Namibia. Windhoek: Republic of Namibia.

South West Africa People's Organisation (SWAPO) (1981) To be Born a Nation: The Liberation Struggle for Namibia. London: Zed Press.

United Nations Institute for Namibia (1986) Namibia: Perspectives for National Reconstruction and Development. Lusaka: UNIN.

World Bank (1991) Poverty Alleviation with Sustainable Growth. Washington, DC: World Bank.

World Bank (2008) Indicators Database 2006. World Bank Country Brief, September 2008. Washington, DC: World Bank.

Global Labour Journal, 2015, 6(3), Page 349 


\section{BIOGRAPHICAL NOTE}

HERBERT JAUCH has been with the labour movement in Southern Africa for many years. He served as executive member of the Namibian National Teachers Union (NANTU) as well as on various committees of the National Union of Namibian Workers (NUNW). For the past eighteen years Herbert worked as a labour researcher, carrying out research projects for various Namibian and Southern African trade unions. Herbert was instrumental in developing a labour diploma course for Namibian trade unions and worked for the trade union-based Labour Resource and Research Institute (LaRRI) in Katutura from 1998 until 2010. He now works as a labour researcher and educator, and heads the education centre of the Metal and Allied Namibian Workers Union (MANWU). [Email: vivaworkers@gmail.com] 